\title{
The many paths to wildlife conservation in Africa
}

T.M. Caro

Simple solutions to wildlife conservation in Africa and elsewhere are comfortable but deceptive. This article focuses on the advantages and disadvantages of the six main methods used to conserve wildlife in Africa and argues that their effectiveness differs according to place and circumstances. The means by which we achieve conservation goals must be employed opportunistically because there is no single path to long-term wildlife conservation.

Many people are united by a common interest in the conservation of wild species and wild places. It is relevant to some solely because they are biologists by profession; for them the study of living things without the necessary raw material has limited scope if their comparative method is to be applied with force (Clutton-Brock and Harvey,
1984). Others sharing this interest are professional conservationists who are actively involved in promoting wildlife or in making recommendations for its protection (Myers, 1979). Yet others are historians and sociologists for whom conservation has the different meaning of conserving land resources for the use of man, but who nevertheless recognize that protecting wild species and wild habitats can greatly contribute to economic development through its important effects on rainfall and soil conservation (Anderson and Grove, 1987). Finally, there are many people who simply enjoy being in the presence of wildlife. All these groups broadly agree that biological conservation is concerned with the prevention of extinction, the maintenance of viable gene pools brought about by individuals reproducing without the help of man (see Frankel

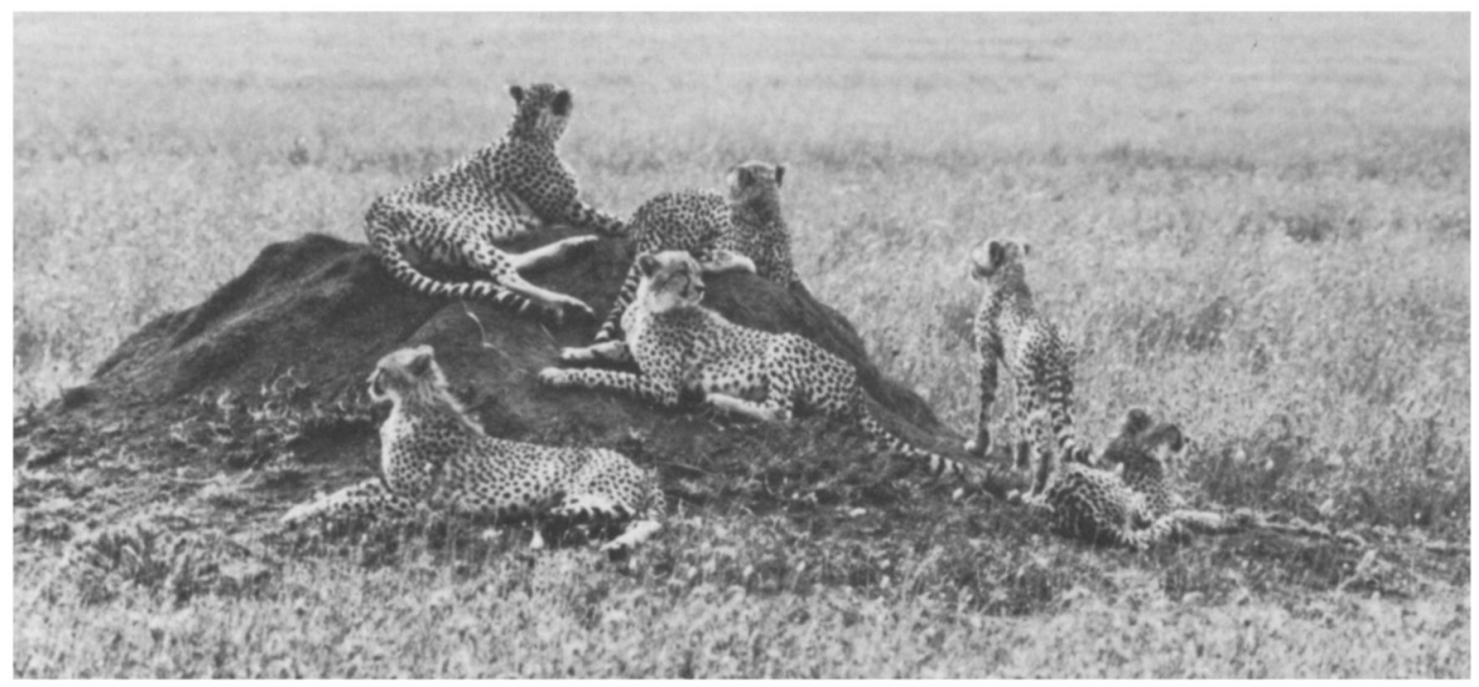

Some argue that preservation of animals for aesthetic reasons is sufficient justification alone (T.M. Caro). 
and Soule, 1981), the preservation of representative examples of wildlife communities, and the protection of catchment and wilderness areas relatively undisturbed by man (Bell, 1983).

Yet, despite this broad commonality of purpose, there is a lack of agreement on the most effective means of achieving the long-term goal of preserving undisturbed areas for posterity and protecting them from direct or indirect disturbance by man in the future. Many have their own pet theories as to which method will be the most effective in ensuring that wildlife and wild places survive into the next millennium. In Africa a number of different methods are being tried, but opinions are polarized and belief in one method is often to the complete exclusion of others (see Parker, 1983, for a case history). Furthermore, some wildife conservationists appear confused and woollyheaded when confronted with the problem of trying to convince others of the merits of wildlife conservation. In many cases they do not appear to have bothered to go to the trouble of separating out and thinking through all the strands of the different arguments we have at our disposal for conserving nature.

In this article I first want to clarify the various arguments that have recently been used to promote the long-term survival of habitats and species and to point out areas of conflict between them. I make the assumption that the proponents of these arguments share the common goal of the long-term preservation of wildlife, but that there are differences as to the best means of achieving it. Then, I aim to show that no single line of reasoning is likely to be effective in conserving species or habitats. Such a unitary approach to wildlife conservation in Africa is at best naive, and at worst immoral, if our endeavours are going to be judged by the survival of wild species in 1000 or 5000 years' time. What conservationists need is a clear understanding of the diverse approaches that can be used to tackle the onslaught of big business, vested interests, local politics, and personal gain, all of which conspire to deplete wildlife resources (Ehrlich and Ehrlich, 1982). By using several approaches, wildlife conservation in Africa may have a better chance of being successful in achieving its goals in the future than it has had in the past.

\section{Can wildlife conservation be justified?}

Before proceeding further, people must examine their own consciences. Do they have the right to persuade developing countries to adopt the goal of long-term biological conservation? The answer is yes for a number of reasons. Firstly, we all learn from the mistakes of others, irrespective of our national boundaries. One mistake made in the West was to cut down too many of the forests and

Table 1. Costs and benefits of different methods used to promote wildlife conservation

\begin{tabular}{|c|c|c|c|c|}
\hline & \multicolumn{2}{|c|}{ Short-term } & \multicolumn{2}{|c|}{ Long-term } \\
\hline & Benefits & Costs & Benefits & Costs \\
\hline Non-economic & $\begin{array}{l}\text { Personal } \\
\text { enjoyment }\end{array}$ & None & $\begin{array}{l}\text { Personal } \\
\text { enjoyment }\end{array}$ & None \\
\hline \multicolumn{5}{|l|}{ Economic } \\
\hline Medicine and products & $\begin{array}{l}\text { Personal } \\
\text { enjoyment }\end{array}$ & None & $\begin{array}{l}\text { New } \\
\text { products }\end{array}$ & Few \\
\hline Tourism & $\begin{array}{l}\text { Foreign } \\
\text { exchange }\end{array}$ & $\begin{array}{l}\text { Habitat } \\
\text { disruption }\end{array}$ & $\begin{array}{l}\text { Foreign } \\
\text { exchange }\end{array}$ & $\begin{array}{l}\text { Demand } \\
\text { may fall }\end{array}$ \\
\hline Big game hunting & $\begin{array}{l}\text { Foreign } \\
\text { exchange }\end{array}$ & $\begin{array}{l}\text { Behavioural } \\
\text { disruption }\end{array}$ & $\begin{array}{l}\text { Foreign } \\
\text { exchange }\end{array}$ & $\begin{array}{l}\text { Demand } \\
\text { may fall }\end{array}$ \\
\hline Cropping & Meat & $\begin{array}{l}\text { Reduced } \\
\text { species }\end{array}$ & Meat & $\begin{array}{l}\text { Reduced } \\
\text { species }\end{array}$ \\
\hline Farming & Meat & $\begin{array}{l}\text { Very few } \\
\text { species }\end{array}$ & Meat & $\begin{array}{l}\text { Loss of } \\
\text { habitat }\end{array}$ \\
\hline
\end{tabular}


eradicate too much of the fauna: wild plants and animals could have survived in areas set aside from human habitation if they had been allowed the space. Conversion of formerly wild habitats to monocultures has a number of consequences. It reduces the number of species available for human use because, not only is biological diversity lowered, but the genetic material on which evolution can act to produce new useful species in the future is reduced. Unfortunately, there are strong arguments to suggest that rare species are the ones most likely to be useful to man (Norton, 1986). Species loss makes it more likely that other interdependent species useful to man will also become extinct, and complex ecosystems are those that are most likely to be able to rejuvenate land abused by man's overexploitation (Norton, 1986). Through incremental effects, this may eventually result in ecological catastrophe that will affect the human species. Furthermore, many would argue that species have intrinsic value and a right to exist (Callicott, 1986). Finally, people derive aesthetic pleasure from wilderness areas (Ehrlich and Ehrlich, 1982) _ just as many people will try to persuade Italians to save Venice for ultimately personal reasons, many others will try to persuade people with outstanding national heritages not to destroy them. No one should be ashamed of putting forward this kind of argument because, ultimately, African peoples and nations have the right to reject our views at any stage that suits them (Lusigi, 1981). In many areas of Africa natural habitats still exist, and it is important for all the world's inhabitants to see that some of those areas remain relatively undisturbed.

\section{Methods used to achieve long-term conservation}

I will now outline the six methods that have been used to further the goal of wildlife conservation in Africa (see Table 1). The first is the only method that is not economic; it states that wildlife should be conserved on 'aesthetic' grounds (in a similar way to conserving art treasures), and that we have a responsibility to preserve natural habitats as we find them today so that future generations can gain aesthetic pleasure from these areas in the same way as we do. Basically then, this is a longterm strategy that excludes the short-sighted, Wildife conservation in Africa selfish use of wildlife now or in the future Tanzania is a country that broadly subscribes to this strategy: 25 per cent of its land has been set aside as wildlife refuges for the express benefit of future generations, although some limited exploitation does occur.

A number of people find this kind of argument rather whimsical and lacking in conviction, although these same people would usually support the upkeep of art galleries and museums (see Bell, 1983, for a discussion). Such antipathy may merely be historical: appreciation of wild places has only recently been regarded as a legitimate leisure activity, whereas art appreciation has a much older history. Nevertheless, even opponents of this view recognize that many people's interest in wildlife conservation began not from utilitarian considerations, but for aesthetic reasons, and that the sentimental value attached to wildlife is an important force in raising funds for conservation. Wildlife and art treasures are not always equivalent, however: unlike art, wildlife can sustain some exploitation because it has the capacity to reproduce. In addition, conflicts between wildlife and people's interests are often direct: wildlife can cause crop damage and can be dangerous, whereas the upkeep of art galleries and acquisition of paintings affects people in only indirect ways, perhaps by reducing funds earmarked for the health services or for food subsidies.

If the preservation of wildlife does impose costs by damaging crops or depriving people of a place to live, other, usually economic, arguments have been used to convince people that eventual benefits of protecting an area will outweigh the current disadvantages (for example, Western, 1982). Thus, the next argument and all subsequent ones mentioned are economic, and are regarded by some as opportunistic because they are often a cover for motivations that are in reality aesthetic (Bell, 1987). The second argument states that the enormous genetic diversity found in wild places may be useful for the benefit of mankind in the future when techniques available for genetic engineering have become more sophisticated and, more importantly, when there is time to discover and experiment with all the products and species that an ecosystem has to 
offer. Myers (1984) has been a vocal proponent of this form of argument in relation to tropical rain forest conservation. Of course, once a substance has been discovered and then manufactured artificially in the laboratory, the forest in which the product is found could lose its importance. This objection is hollow because ecosystem diversity is so great that there will always be other organic compounds that have considerable value for medicine and consumer products (Ehrlich and Ehrlich, 1982; Myers, 1983; Lovejoy, 1986).

This argument lays emphasis on the integrity of the ecosystem as a whole rather than on preserving certain species or subsections of the ecosystem. It is now recognized that many economically important plant species are only able to exist because of microclimates maintained by other species or through the protection that other plants and insects afford them (Ehrlich and Ehrlich, 1982). A well-known example is the coevolution of fig species and the fig wasps that pollinate them (Galil, 1977). This argument for conserving wildlife habitats, therefore, conflicts little with the first, non-economic method.

The third argument is that wildlife should be appreciated by current generations, with less regard being paid to the consequences that visitors might have on the future of wilderness areas. The accent is on seeing and experiencing now rather than preserving for the future. Thus, Kenya's national park system is built on an uneasy truce between protecting animals for the local population's edification now and in the future (see Pyle, 1980), and on exploiting it for the foreign revenue it currently brings in. Photographic safaris have at times been one of Kenya's most important earners of foreign exchange (Eltringham, 1984), and it is clear that economic benefits are an important consideration in many politicians' eyes.

However, pursuit of short-term gains in this way may reduce the probability that an ecosystem will survive for another 1000 years, and thus cancel long-term gains. The most important worry is that tourism, like any other industry, is subject to market forces. Changes in prices of fuel or spare parts can make African safaris expensive for clients and uneconomic to run, and political instability even in neighbouring states can have a 224 devastating effect on the number of tourists visiting a country. Both of these problems have already occurred in East Africa in the last 10 years (Eltringham, 1984; Sindiyo and Pertet, 1984). In addition, heavy tourism can have other, less welldocumented effects: it can destroy vegetation and may even stress animals to a degree that could affect their rates of reproduction (see, for example, Henry, 1977). Tourist facilities are also beginning to take up an increasingly large proportion of areas set aside for animals and plants, as is currently occurring in the Masai-Mara Game Reserve in Kenya (Caro, 1986).

The fourth argument goes further: it states that some of the wildlife population must be shot to ensure that the bulk of its members can continue to live in relatively undisturbed conditions (Anderson, 1983). One of the many ways of doing this is to let big game hunters shoot wild animals for large sums of foreign exchange. This form of wildlife exploitation is basically geared to short-term pay-offs, but may have long-term benefits. It is being employed now in many African countries, perhaps most notably in Zimbabwe and South Africa, and can be convincingly used in some circumstances to construct policies that stop agriculture from encroaching on wilderness areas because the profits from big game hunting have, to date, been large. It has also been used as a source of revenue in managing wild animal populations that have undergone explosions in or around national parks (Cumming, 1981).

Big game hunting recognizes the need to preserve natural habitats and ecosystems because it is necessary to maintain a diverse array of large species for hunters to shoot. However, hunting

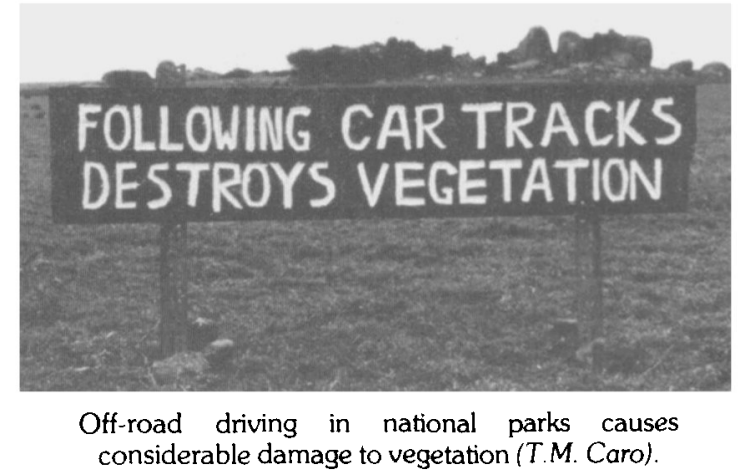

Oryx Vol 20 No 4. October 1986 


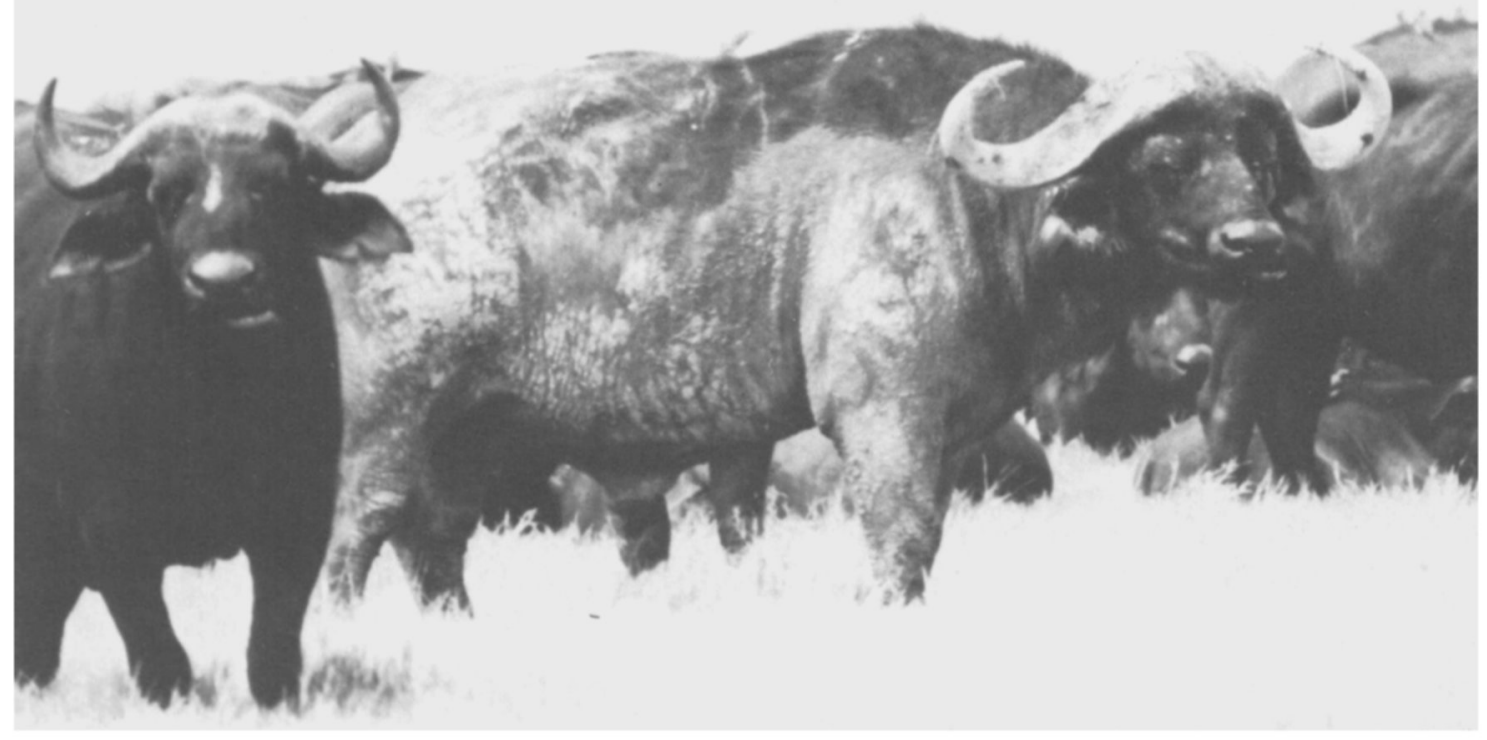

Buffalo are important for any big game hunter's bag (T.M. Caro).

causes considerable disruption because it alters the relative abundance of some species, such as large carnivores; it is difficult to shoot certain species selectively (for example, leopards); its effects on the social structure of groups can radically lower recruitment (for example, lions) (Caro, 1984), and it causes behavioural changes by making species wary of man's presence. This method therefore runs into conflict with other methods that lay emphasis on the educative or research benefits derived from wildlife, and on tourism, which relies on viewing relatively tame animals (but see Anderson, 1983).

The fifth argument used in furthering wildlife conservation in Africa has been the sustainable cropping of wild herbivores (see Bell, 1983, for a clear discussion of its advantages and disadvantages). Here a percentage of the animal population is cropped, often by shooting, the meat is sold locally, and any animal products are normally taken by the central authorities. Eltringham (1984) has provided a detailed account of the limitations of harvesting wildlife populations, and has concluded, in contrast to some authorities, that in much of Africa, in the 1960 s and 1970s at least, the monetary benefits Wildife conservation in Africa were rather marginal. In countries where lines of communications are long and transport is problematic, the financial costs become large and the logistics difficult. However, there is no doubt that the financial benefits of game cropping are increasing in some countries in southern Africa (Luxmoore, 1985), in part because processing techniques are becoming more efficient and also because draconian measures have been taken to limit the spread of disease (Owens and Owens, 1983; Williamson and Williamson, 1984).

The cropping of animals puts much emphasis on short-term gains, and long-term considerations usually suffer. For example, cropping programmes reduce the genetic diversity of a population and so speed up the process of inbreeding (see Soule, 1980). They reduce the stability and resilience of a population in a number of ways that make it less able to deal with future environmental changes (Caughley, 1983). They disrupt wildlife far more than does big game hunting (Caughley, 1979), and in habitats set aside for cropping schemes, efforts are often taken to get rid of 'nuisance' predator species and to concentrate on maintaining only a few economically viable species of ungulates, rather 
than the whole spectrum of wild animals (Luxmoore, 1985).

The last argument used in promoting conservation in Africa is the farming of wild animals. This method is limited to a few suitable species and as an alternative or addendum to domestic grazing species (Crawford, 1974). There are good economic reasons for keeping ory $x$ in areas too arid for cattle (Coe, 1980), and game farming may be a viable economic proposition for many species of small antelope like springbok or impala (Skinner, 1985). Yet such exploitation may soon lead to domestication and the keeping of species only under captive conditions, and it thus lays emphasis on relatively short-term financial rewards rather than on the saving of wild habitats in which many species can live. Game farming or ranching cannot normally tolerate indigenous predators, for example, unless it is combined with big game hunting (Pitman, 1984). Eventually most wild species could be removed from the wild and be factory-farmed, as are alligators in the southern United States, thereby removing the need to preserve the habitat occupied by other, less commercially useful species (Collar, 1986).

\section{The need for plurality of approaches}

The World Conservation Strategy (Anon., 1980) has formulated a single, utilitarian approach to conservation that embraces all the economic methods. The document states that 'the preservation of genetic diversity is both a matter of insurance and investment-necessary to sustain and improve agricultural, forestry and fisheries production, to keep open future options, as a buffer against harmful environmental change, and as the raw material for much scientific and industrial innovation - and as a matter of moral principle'. The 'moral principle' is that 'we cannot predict what species may become useful to us', and many may one day provide 'important products, such as pharmaceuticals'. Reliance on economics alone is unlikely to be in the best interests of the long-term survival of all areas in danger of destruction (Bell, 1987), especially if it maximizes short-term pay-off to the detriment of long-term prospects, implicit in the argument proposed by the World Conservation Strategy. Nevertheless, there is no doubt that each nation has its own specific problems, and the path to conservation must be tailored to suit the particular needs of each area in each country.

However, what works in one area today may not be very effective in another region within the same country or in different countries. The grafting of a new economic method of wildlife

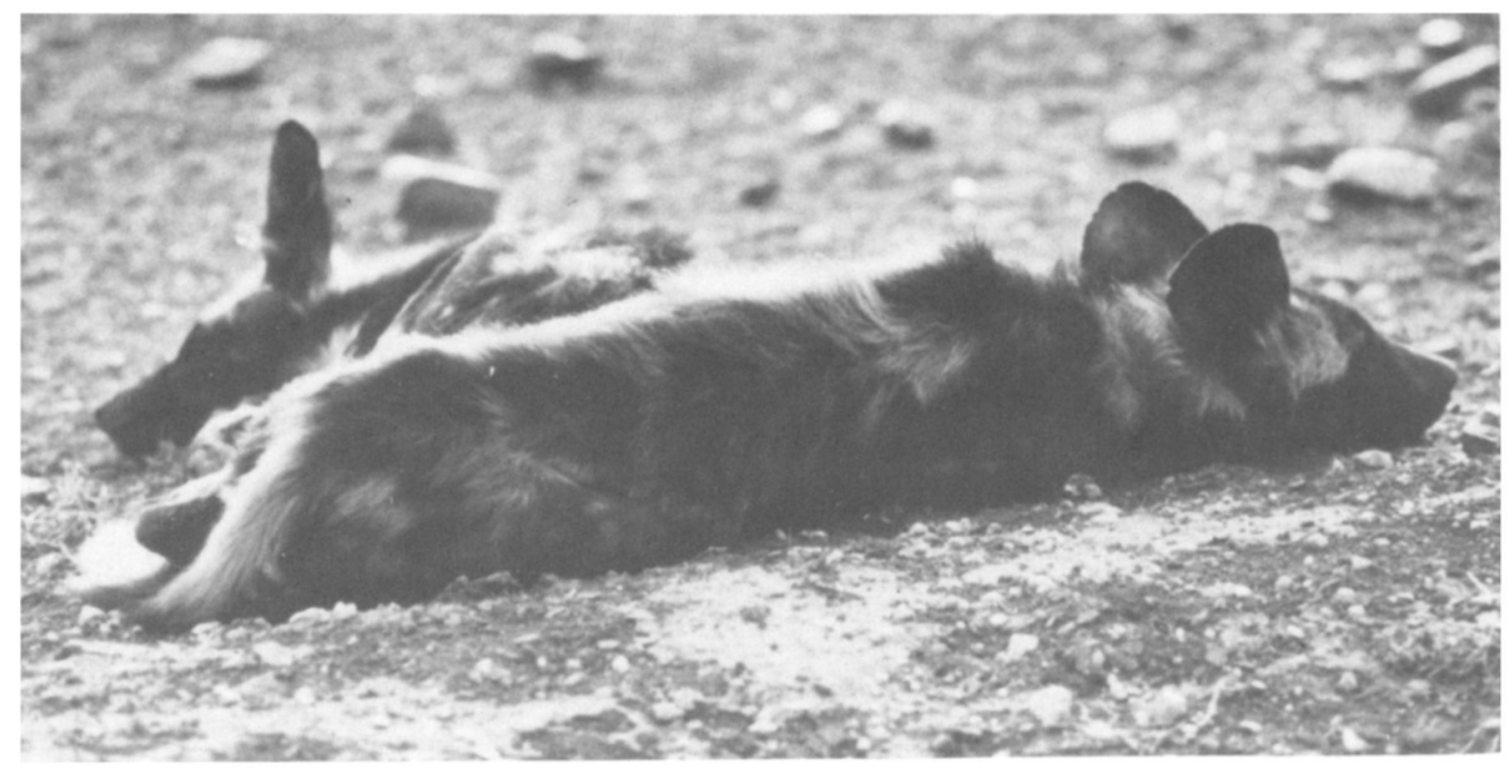

Nuisance predators such as these wild dogs are eliminated from game ranches (T.M. Caro). 
protection on to an existing one is often inappropriate. For instance, conservation in Tanzania was primarily founded on non-economic considerations and is in a relatively healthy state. Trying to crop animals in Tanzania Parks is not only unnecessary, but would be impossible logistically (Nevertheless, this is not to say that wildlife cropping does not work well in Zimbabwe.) If interested parties do try to promote their cropping schemes in situations where conservation is working well, and at present a number of vocal people are trying to apply these utilitarian schemes to a wide range of circumstances, we have to question seriously their long-term conservation motives and examine their economic interests a lot more closely.

Yet even the most appropriate method we use to help people conserve their wildlife now may not be the best in 30 or 300 years' time. In the 1920 s it would have been foolish to base ostrich conservation entirely on the economic benefits gained from farming them; ostrich feathers have long since gone out of fashion (Eltringham, 1984). Any economic method is ultimately subject to change in demand (Clarke, 1972), so it is quite possible that lucrative big game hunting will eventually cease because of becoming socially unacceptable, or even that photographic safaris on the large scale now practised will be made impossible by huge petrol price increases.

The point is that no one method is likely to be better than all others in all circumstances. There are vast differences between Francophone and Anglophone Africa, between relatively well-off countries such as the lvory Coast and poor countries such as Somalia, and between countries that have suffered political instability such as the Central African Republic, and those with a more stable political background such as Botswana. The problem facing wildlife conservationists is not to decide what is the best approach to use in the abstract, as the World Conservation Strategy has done, but to decide which approach or approaches will have the greatest beneficial impact for conservation in the long-term in a given situation. For example, in situations where population density is high, local people must be convinced that moving into a reserve or protected area only delays the problem of overcrowding for a few more years. This may have to be backed up with direct economic returns and giving people a stake in the revenue gained from tourism or big game hunting (but see Lindsay, 1987). Alternatively, central government may need to be convinced that cropping schemes in one area can feed people in another region, or that relict habitats are worth preserving for their intrinsic value or have the possibility of

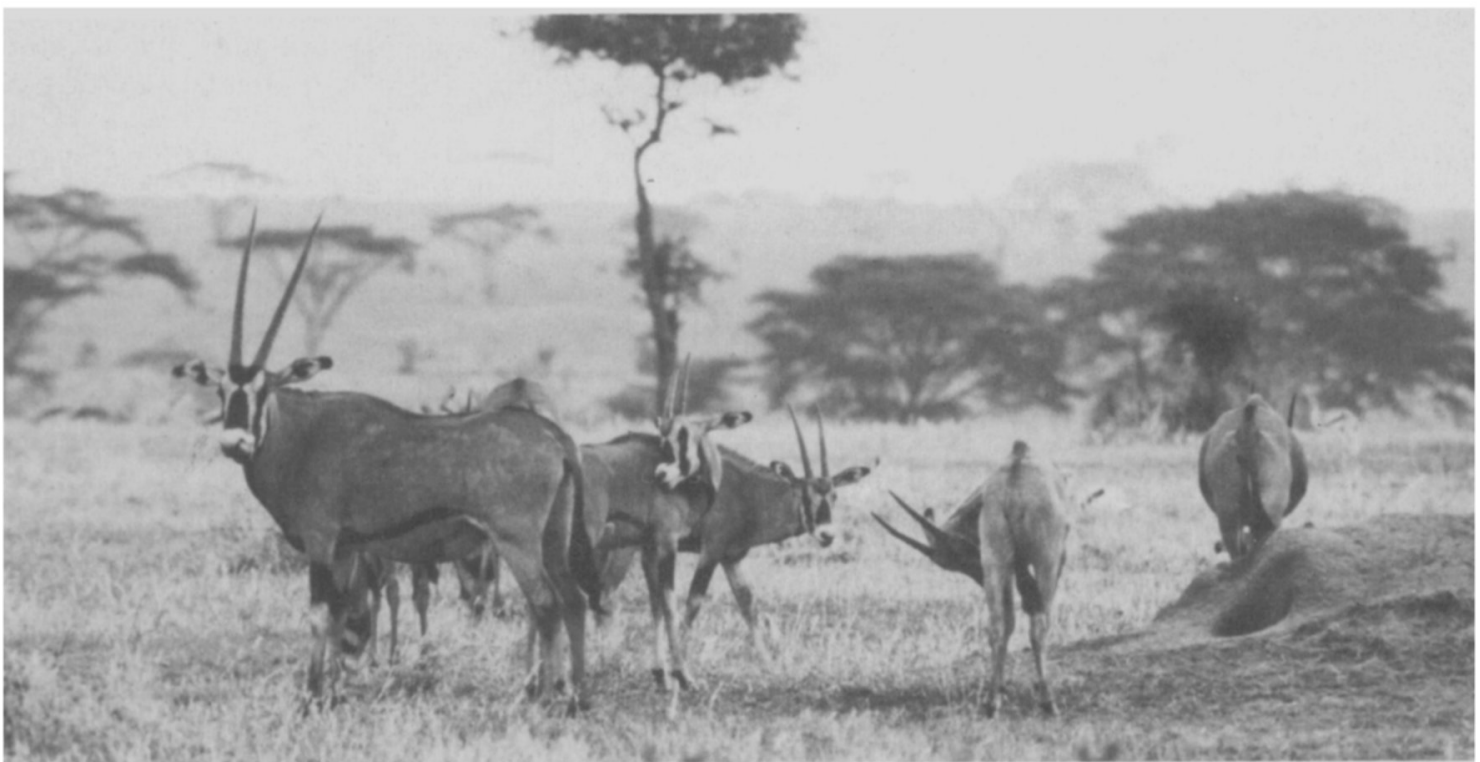

Oryx can be farmed in certain areas (T.M. Caro). 


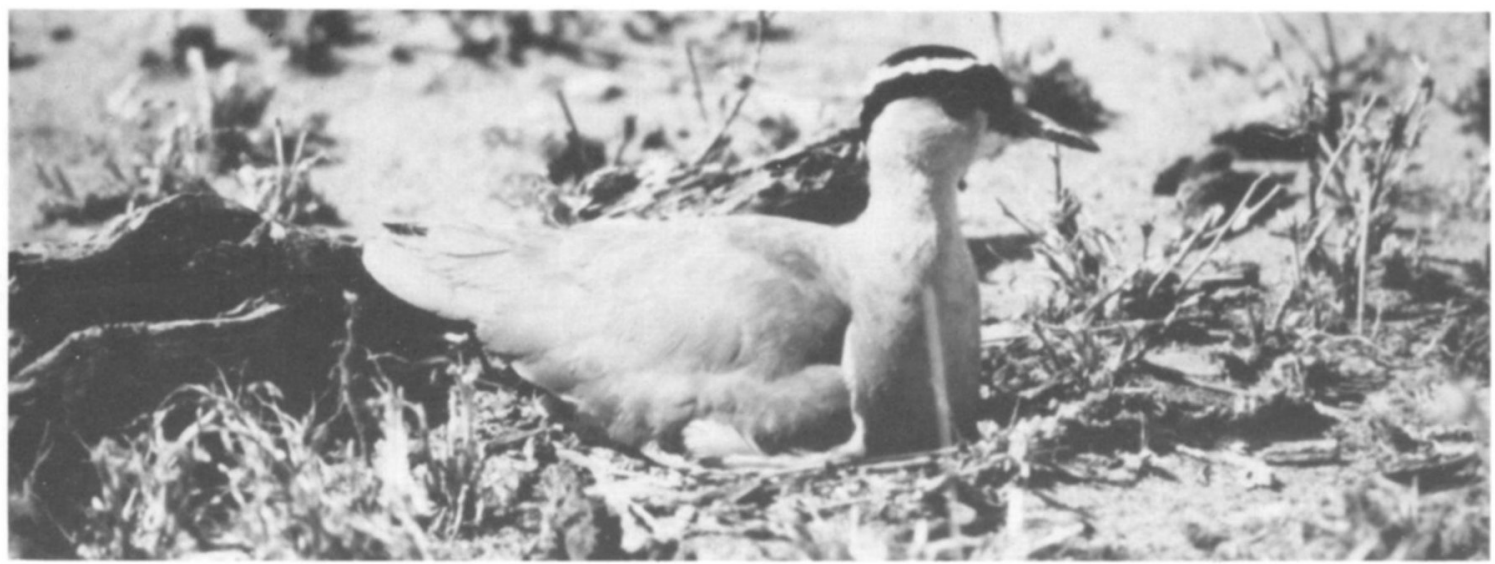

Most economic methods for promoting conservation make no provision for preserving inconspicuous animals such as this plover (T.M. Caro).

supplying new strains of profitable food items (Myers, 1983). Certainly emphasis need not always be placed on short-term pay-offs, for governments do regularly recognize that longterm considerations are important in other situations; for example, when balanced against the long-term pay-offs of building a hydroelectric scheme, the disruption of relocating people is usually thought to be worthwhile. In addition, methods may have to be used in conjunction with each other, and wilderness areas zoned so that people's different needs are served simultaneously. Some of the most successful game ranches are combining several of these approaches (Luxmoore, 1985).

In order to decide upon which method is the most appropriate in a given situation, we are going to have to compare each method using a common currency. It is relatively easy to work out the benefits of some of the economic arguments in the immediate future: financial extrapolations can often be made from existing tourist programmes or cropping schemes, and reasonable predictions can be made in relation to the area under discussion. Assigning figures to long-term costs of, for example, disruption caused by cropping or the existence of tourist amenities is going to be far more difficult, but it must be attempted. Perhaps a reduced spectrum of species living in an area is less acceptable if those species are not represented in other protected habitats, or if the area is near to a city where it might be used for educating and stimulating large numbers of young people. 228
In addition, the non-economic argument may have to be given some sort of economic weighting if it is to be a convincing alternative to other methods. Personal enjoyment can be measured to some extent. The amount of time people spend in national parks is known in some Western countries, and questions as to the distance people travel, or the amount they will pay to see wildlife, can be used to gain an idea of how much people value their natural heritage. Many of these sorts of judgements are already being used in an informal way, but if we are to re-emphasize the importance of long-term considerations, we are going to have to make a concerted attempt at quantifying the future costs and benefits of a strategy we propose to employ now.

In summary, the goal of long-term wildlife conservation must be pursued opportunistically. The most effective way to save areas from destruction and species from extinction must be employed as rapidly as possible, its effectiveness continually reassessed, and new methods employed as soon as old ones cease to work. Also, to be effective in achieving the goal of biological conservation, we must discuss and promote these issues incisively and with a greater clarity of thought than we are used to.

\section{Acknowledgments}

Discussions with David Babu, Marcus Borner, Joe Cheffings and Alan Root helped me formulate some of the arguments presented here. Monique Borgerhoff Mulder, Patrick Duncan, Phyllis Lee, Keith Lindsay, John Scherlis, Douglas Williamson 
and an anonymous referee kindly commented on the manuscript, although none of these people necessarily subscribes to the views put forward.

\section{References}

Anderson, D. and Grove, R. 1987. Conservation in Africa: Policies and Practice. Cambridge University Press, Cambridge (in press).

Anderson, J.L. 1983. Sport hunting in national parks: sacrilege or salvation. In Management of Large Mammals in African Conservation Areas. (Ed. R. N. Owen-Smith), pp. 271-280. HAUM Educational Publishers, Pretoria.

Anon. 1980. World Conservation Strategy. International Union for Conservation of Nature and Natural Resources, Gland, Switzerland.

Bell, R.H.V. 1983. Decision-making in wildlife management with reference to problems of overpopulation. In Management of Large Mammals in African Conseruation Areas (Ed. R. N. Owen-Smith), pp. 145-186. HAUM Educational Publishers, Pretoria.

Bell, R.H.V. 1987. Conservation with a human face: conflict and reconciliation in African land use planning. In Conservation in Africa: Policies and Practice. Cambridge University Press, Cambridge (in press).

Callicott, J.B. 1986. On the intrinsic value of nonhuman species. In The Preservation of Species: the Value of Biological Diversity (Ed. B. G. Norton), pp. 138-172. Princeton University Press, Princeton, $\mathrm{NJ}$.

Caro, T. 1984. Big game hunters are not biologists. New Scientist. 1434, 12-15.

Caro, T. 1986. Tourism: too much of a good thing? Swara (in press).

Caughley, G. 1979. What is this thing called carrying capacity? In North American Elk: Ecology. Behaviour and Management (Eds M. S. Boyce and L. D. Hayden-Wing), pp. 2-8. University of Wyoming, Laramie.

Caughley, G. 1983. Dynamics of large mammals and their relevance to culling. In Management of Large Mammals in African Conservation Areas (Ed. R. N. Owen-Smith), pp. 115-126. HAUM Educational Publishers, Pretoria.

Clarke, J. 1972. One man's view. Black Lechwe Magazine. 10, 29-33.

Clutton-Brock, T.H. and Harvey, P.H. 1984. Comparative approaches to investigating adaptation. In Behavioural Ecology: An Evolutionary Approach (Eds J. R. Krebs and N. B. Davies), pp. 7-29. Blackwell Scientific, Oxford.

Coe, M. 1980. African wildlife resources. In Conservation Biology: An Evolutionary-Ecological Perspective (Eds M. E. Soule and B. A. Wilcox), pp. 273-302. Sinauer Associates Inc., Sunderland, MA.

Collar, N.J. 1986. Species are a measure of man's freedom: reflections after writing a red data book on African birds. Oryx, XX, 15-19.

Crawford, M.A. 1974. The case for new domesticated animals. Oryx. XII, $351-360$.

Cumming, D.H.M. 1981. The management of elephant and other large mammals in Zimbabwe. In Problems in Management of Locally Abundant Wild Mammals (Eds P. A. Jewell, S. Holt and S. Dart), pp. 91-118. Academic Press, New York.

Ehrlich, P. and Ehrlich, A. 1982. Extinction: The Causes and

Wildife conservation in Africa
Consequences of the Disappearance of Species. Victor Gollancz, London.

Eltringham, S.K. 1984. Wildlife Resources and Economic Development. John Wiley \& Sons, Chichester.

Frankel, O.H. and Soule, M.E. 1981. Conservation and Evolution. Cambridge University Press, Cambridge.

Galil, J. 1977. Fig biology. Endeavour, 1, 52-56.

Henry, W.S. 1977. Tourist impact on Amboseli National Park. Wildlife News, 12(2), 4-8.

Lindsay, W.K. 1987. Integrating parks and pastoralists: some lessons from Amboseli. In Conservation in Africa: Policies and Practice (Eds D. Anderson and R. Grove). Cambridge University Press, Cambridge (in press).

Lovejoy, T.E. 1986. Species leave the ark one by one. In The Preservation of Species: The Value of Biological Diversity (Ed. B. G. Norton), pp. 13-27. Princeton University Press, Princeton, NJ

Lusigi, W.J. 1981. New approaches to wildlife conservation in Africa. Ambio, 10, (2-3), 87-92.

Luxmoore, R. 1985. Game ranching in South Africa as a force in conservation. Oryx, XIX, 225-231.

Myers, N. 1979. The Sinking Ark. Pergamon Press, New York.

Myers, N. 1983. A Wealth of Wild Species: Storehouse for Human Welfare. Westview Press, Boulder, CO.

Myers, N. 1984. The Primary Source: Tropical forests and Our Future. W.W. Norton \& Co., New York.

Norton, B.G. 1986. On the inherent danger of undervaluing species. In The Preservation of Species: The Value of Biological Diversity (Ed. B. G. Norton), pp. 110-137. Princeton University Press, Princeton, NJ.

Owens, M. and Owens, D. 1983. Fences of death. Wildlife, June, 214-217.

Parker, I.S.C. 1983. The Tsavo story: an ecological case history. In Management of Large Mammals in African Conservation Areas (Ed. R. N. Owen-Smith), pp. 37-49. HAUM Educational Publishers, Pretoria.

Pitman, R. 1984. Utility and sorrow. BBC Wildlife, 2(2), 7681.

Pyle, R.M. 1980. Management of nature reserves. In Conservation Biology: An Evolutionary-Ecological Perspective (Eds M. E. Soule and B. A. Wilcox), pp. 319-327. Sinauer Associates Inc., Sunderland, MA.

Sindiyo, D.M. and Pertet, F.N. 1984. Tourism and its impact on wildlife conservation in Kenya. Swara, 7, 13-17.

Skinner, J.D. 1985. Wildlife management in practice: conservation of ungulates through protection or utilization. Sump. Zoo. Soc. Lond. 54, 25-46.

Soule, M.E. 1980. Thresholds for survival: maintaining fitness and evolutionary potential. In Conservation Biology: An Evolutionary-Ecological Perspective (Eds M. E. Soule and B. A. Wilcox), pp. 151-169. Sinauer Associates Inc., Sunderland, MA.

Western, D. 1982. Amboseli National Park: enlisting landowners to conserve migratory wildlife. Ambio, 11, 302308

Williamson, D. and Williamson, J. 1984. Botswana's fences and the depletion of Kalahari wildlife. Oryx. XVIII, 218222 .

T. M. Caro, Sub-Department of Animal Behaviour, University of Cambridge, Madingley. Cambridge CB3 8AA, UK. 